\title{
Sustainability Governance at Higher Education Institutions: Equipped to Transform?
}

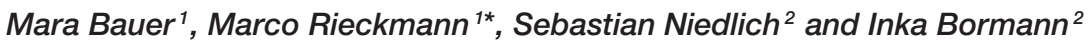 \\ ${ }^{1}$ Department of Education, Faculty of Education and Social Sciences, University of Vechta, Vechta, Germany, ${ }^{2}$ Department \\ of Education and Psychology, Freie Universität Berlin, Berlin, Germany
}

Keywords: higher education, sustainable development, governance, transformation, policy

\section{INTRODUCTION}

Higher education institutions (HEIs) have various opportunities to engage in and foster sustainable human progress. They can thus play a decisive role in promoting sustainable development (SD) by integrating sustainability as a cross-cutting principle in teaching, research, operations, and knowledge transfer (cf. Sterling, 2013).

In this opinion paper, we reflect on selected literature as well as on specific research we have conducted into sustainability governance at German HEIs. We then provide answers to the following questions (in a German context): Is it essential for HEIs to promote SD? What constitutes optimal sustainability governance at HEIs? And what progress has been made with implementation? We conclude the article with a discussion of current resistance and future

Edited by: lain Stewart, University of Plymouth, United Kingdom

Reviewed by:

Federica Doni,

University of Milano-Bicocca, Italy Wendy Purcell,

Harvard University, United States

*Correspondence:

Marco Rieckmann

marco.rieckmann@uni-vechta.de

Specialty section:

This article was submitted to

Sustainable Organizations,

a section of the journal

Frontiers in Sustainability

Received: 11 December 2020

Accepted: 29 March 2021

Published: 26 April 2021

Citation:

Bauer M, Rieckmann M, Niedlich S and Bormann I (2021) Sustainability

Governance at Higher Education Institutions: Equipped to Transform?

Front. Sustain. 2:640458

doi: 10.3389/frsus.2021.640458

\section{IS IT ESSENTIAL FOR HEIS TO PROMOTE SUSTAINABLE DEVELOPMENT?}

\begin{abstract}
"Higher education is at the crossroads having to choose between the path of commodification of knowledge creation and learning focusing on optimization and efficiency with the wellbeing of the economy as a key driver or the path of socio-ecological transitions requiring new forms of research and learning as well as alternative capabilities and values that contribute to the well-being of planet and people" (Wals et al., 2016, p. 36).
\end{abstract}

We hold this to be true and urge higher education institutions to choose the latter course of action. In the face of current sustainability crises, the survival of global society depends on competencies that have so far been of little relevance due to longstanding ignorance of the consequences of our exploitative economic system. The complexity that is inherent in socio-ecological challenges such as climate change requires new forms of learning, thinking, and engagement with the world that are truly transformative and transgressive (Sterling, 2011; Lotz-Sisitka et al., 2015; Wals et al., 2016, p. 28). HEIs are well-placed to explore concepts relating to this issue, disseminate them on a large scale and involve a broad range of disciplines.

To date, however, most HEIs still contribute to the maintenance of a system that is geared toward economic growth and ignores the ecological limits of the planet (Fazey et al., 2020). All too often, students still do not have the opportunity to adequately address global challenges in their studies, or they are only confronted with information about the causes and development of the climate crisis, for instance, in lectures or similar, which does not allow for a transformative learning process (Singer-Brodowski et al., 2019). But global challenges call for them to be empowered to think in a systemic and forward-looking way and to contribute to solving complex social problems 
(Orr, 1991; Glasser, 2005; de Haan, 2010; Fadeeva and Mochizuki, 2010; Rieckmann, 2012; Brundiers et al., 2021). In addition to teaching and research, HEIs can provide platforms where co-creation and collaboration between people and institutions from different scientific or societal backgrounds address the increasing complexity of real life problems (Giesenbauer and Müller-Christ, 2020).

It has often been argued that the normativity of sustainability (science) stands in conflict with the traditional positivistic theory of science and the freedom of research. Vogt and Weber (2020) refute this argument by stating that "[s]cientists are involved from the beginning in social change - as soon as they begin to produce ideas and discourses. It is their task to reflect upon this situation" (Vogt and Weber, 2020, p. 17). In doing so, they might become aware of the responsibilities they are entrusted with, being "the voice of the ones without a voice in the arena of power" (Vogt and Weber, 2020). This, in a nutshell, turns the tables and ultimately means science has an ethical obligation to engage constructively with SD or at the least to refrain from promoting unsustainability since "value-free research is neither possible nor desirable" (Vogt and Weber, 2020).

We will now take a closer look at the concepts and structures that can help HEIs to implement SD once their members have embarked on this learning journey together.

\section{WHAT CONSTITUTES SUSTAINABILITY GOVERNANCE AT HEIS?}

One major aspect of successful governance for SD at HEIs that many agree upon is the whole institution approach (Sterling, 2004; Ferrer-Balas et al., 2008; Hoover and Harder, 2015; SingerBrodowski et al., 2019). The development of an approach to the implementation of SD that integrates research, teaching, knowledge transfer, and operations is a complex but worthwhile challenge for HEI governance and can eventually transform entire institutions. We support this concept and would suggest the adoption of an "all-dimensions approach," namely one that integrates the multiple dimensions of SD and is based on a common understanding between all those developing crosssectoral measures. This broadens perspectives and opens up opportunities to engage an even greater variety of stakeholders (Bauer et al., 2020).

Another essential factor that is also promoted by a whole institution approach is the HEI's commitment to engaging, and ability to engage, in a challenging learning process. In a multi-case study involving 11 German HEIs, we identified two components that played a key role in organizations' approach to learning in the context of SD: the HEIs own perception of their purpose and the assignment of responsibility within HEIs. We found that institutions that viewed themselves as members of society and considered that they had an obligation to participate in shaping it going beyond the obvious tasks of research and teaching usually had a variety of structures in place that enabled regular interaction and cooperation with other stakeholders (Niedlich et al., 2019). This "co-evolutionary rather than linear view of the relationship between education and society" (Sterling, $2004,67 f$.) opens up new ways of learning_individually and as an organization, and especially with regard to urgent social issues such as unsustainability. Ferrer-Balas et al. (2008), furthermore, show that close links between HEIs and society are an important driver of organizational transformation, since they communicate society's demand for SD more directly to HEIs and therefore intensify the pressure to act.

In contrast, the second component of organizational learning is situated inside the institutions themselves. It has been shown that HEIs take highly divergent approaches to the assignment of responsibility for SD processes (Niedlich et al., 2019). In this regard, it is considered beneficial to have a "structure of responsibility, emphasizing the development of sustainability as a joint development process encompassing all of its stakeholders" (Niedlich et al., 2019, p. 9) rather than a top-down approach. Participation, dialogue and cooperation between stakeholders from different fields and sectors are key (Disterheft et al., 2015; Hoover and Harder, 2015; Leal Filho et al., 2019). This corresponds with a notion of responsible leadership as "being facilitative rather than directive in order to allow everyone, staff and students, to take responsibility to lead, accept risk and find ways to innovate" (Davis and Goedegebuure, 2017, p. 226) and has some similarities with the discourse on distributed leadership (Bolden et al., 2009) and social networks (Purcell et al., 2019). Governance structures such as open Round Tables, transdisciplinary task forces, and Green Offices can be ways to apply this concept. However, it should be noted that voluntary engagement has its limits and that structures such as these depend on reliable funding.

This last remark foreshadows the final section of this paper where we discuss other ways in which HEI governance for SD, as depicted here, can be promoted. But first, we will take a look at Germany, and examine what HEIs have already been able to achieve.

\section{WHAT PROGRESS HAS BEEN MADE WITH IMPLEMENTATION?}

In 2006, Adomßent and Michelsen criticized the low number of German HEIs that were committed to SD and attributed this primarily to the "lack of an adequate framework for a consistent and concise German higher education policy that provides universities with financial and legal instruments to commit themselves to sustainable development in reliable ways" (Adomßent and Michelsen, 2006, 88). Only a few years later, Adomßent (2010) was already sounding relatively optimistic with regard to the impact of a number of scientific and social stimuli for increased sustainability on the German HEI landscape. However, progress was generally selective and focused on individual parts of HEIs, with whole-institution approaches being far from common. Lozano et al. (2015) also noted this in their worldwide study on sustainability implementation by 70 HEIs. This still appears to be the case, at least in Germany, as Singer-Brodowski et al. (2019) have shown (Germany is the example we have taken, but the situation is not very different in many other countries, cf. Leal Filho et al., 2019; Fazey et al., 2020). Singer-Brodowski et al. (2019) furthermore detected a 'Beacon Strategy' with regard to German HEIs' ambitions to integrate SD through a whole-institution approach: only a handful of 
HEIs have declared themselves SD pioneers, managed to fully institutionalize the concept and thus seemingly outdistanced other HEIs (Helling, 2018; Schmitt and Palm, 2018; SingerBrodowski et al., 2019; cf. Niedlich et al., 2019). However, the "Beacon Strategy" seems to be working, since the spread of SD-related experiences and knowledge throughout the scientific community also helps to reinforce SD practices-hopefully also beyond the beacons' own premises.

Finally, signs of this kind of development are evident in the HEIs' sustainability network, which has been established over the last 4 years as part of a German collaborative project and which now includes stakeholders from over 130 of the approximately 400 HEIs in Germany (see www.hochn.uni-hamburg.de/en.html). Having been part of this project ourselves, we acknowledge the efforts being made. Meanwhile, we can certainly see some HEIs that are already aiming to catch up with those few that have gone before them.

\section{THE CHALLENGES AND POTENTIAL OF A SUSTAINABLE HIGHER EDUCATION SYSTEM}

Although an HEIs' official commitment to SD has been identified by Lozano et al. (2015) as correlating with their implementation of SD, the path certainly entails more obstacles than that. HEIs are complex organizations where change cannot be brought about in the short term. Rather, the process of change is accompanied by complex learning processes on the part of the individuals in the various parts of the organization. Together, these mean that HEIs undergo comprehensive change processes in the course of which established and proven routines, but also goals and processes, are (or can be) questioned and realigned. In the course of this, the interests and rationales of different groups of higher education stakeholders will clash, so that an HEI on the path to sustainability can be said to be learning, and can therefore be seen as a place where education for sustainable development is taking place.

In order for this potential to be developed, some essential external factors must be considered. As of now, the higher education system does not seem ready to support the interand transdisciplinary teaching and learning environments that education for sustainability calls for (Singer-Brodowski et al., 2019). This is also true with regard to research, knowledge transfer, and campus operations. Overall, many HEIs see themselves as committed to competing rationales that undermine the requirements necessary for contributing to SD. They are confronted with a multitude of demands and challenges such as internationalization, digitization and marketization (Altbach, 2008; Giesenbauer and Tegeler, 2020). Meanwhile, policymakers have not formulated any recognizable basis for prioritizing tasks or provided any incentives to support such prioritization, despite

\section{REFERENCES}

Adomßent, M. (2010). Hochschule und Nachhaltigkeit. Eine kritische Bestandsaufnahme. ZEP - Zeitschrift für internationale Bildungsforschung the many (non-binding) agreements and declarations relating to SD at HEIs at various levels of governance (Adomßent and Michelsen, 2006; Michelsen, 2016; Singer-Brodowski et al., 2018). Instead, the competition for scientific excellence prevents participating HEIs from engaging in alternative activities. Mono-disciplinary research is often still accorded greater value than innovative citizen science, to name one example, as current funding programs clearly demonstrate. Adjustment to funding mechanisms could address inter alia the often highlighted shortcomings of HEIs with regard to the exchange of knowledge with other stakeholders in society (Zilahy and Huisingh, 2009; Trencher et al., 2014; Leal Filho et al., 2019), and therefore could also benefit the pursuit of the so-called third mission.

However, prioritization and funding are also issues that, to a certain extent, HEIs can arrange individually according to their own agendas. As set out above, SD implementation requires reasoned conceptions of, and structures for, SD. By making resources permanently available, HEI management can make an important statement and facilitate a far-reaching process of development toward SD. Some HEIs have already been able to set high standards for SD, seizing the opportunity to become beacons for sustainability and thus becoming particularly attractive to students and staff. A small number of beacons is not sufficient, but when the numbers increase, this unique advantage is removed. We need to move past this tipping point toward an HEI landscape where not being sustainable makes an HEI undesirable.

In closing, we would like to stress that HEIs need to undergo a fundamental transformation, and focus on principles of responsibility and sustainability. HEIs should see themselves as laboratories in which students learn to critically examine social conditions, develop ideas for a better future and implement sustainable solutions. In this way, HEIs will make a tangible contribution to the well-being of mankind.

\section{AUTHOR CONTRIBUTIONS}

$\mathrm{MB}$ and $\mathrm{MR}$ : first draft. $\mathrm{MB}, \mathrm{MR}, \mathrm{SN}$, and $\mathrm{IB}$ : revisions and project administration. MR and IB: supervision and funding acquisition. All authors have read and agree to the published version of the manuscript.

\section{FUNDING}

This research was funded by the Bundesministerium für Bildung und Forschung, Germany, Grant/Award Number: 13NKE007A.

\section{ACKNOWLEDGMENTS}

The authors would like to thank two reviewers for their critical and constructive feedback.

und Entwicklungspädagogik 33, 33-34. Available online at: https://www. waxmann.com/index.php?eID=download\&id_artikel=ART100892\&uid=frei Adomßent, M., and Michelsen, G. (2006). German Academia heading for sustainability? Reflections on policy and practice in teaching, 
research and institutional innovations. Environ. Educ. Res. 12, 85-99. doi: 10.1080/13504620500527758

Altbach, P. G. (2008). "The complex roles of universities in the period of globalization," in Higher Education in the World 3-Higher Education: New Challenges and Emerging Roles for Human and Social Development, ed Global University Network for Innovation (London: Palgrave Macmillan), 5-14.

Bauer, M., Niedlich, S., Rieckmann, M., Bormann, I., and Jaeger, L. (2020). Interdependencies of culture and functions of sustainability governance at higher education institutions. Sustainability 12:2780. doi: 10.3390/su12072780

Bolden, R., Petrov, G., and Gosling, J. (2009). Distributed leadership in higher education: rhetoric and reality. Educ. Manage. Administr. Leadersh. 37, 257-277. doi: 10.1177/1741143208100301

Brundiers, K., Barth, M., Cebrián, G., Cohen, M., Diaz, L., Doucette-Remington, S., et al. (2021). Key competencies in sustainability in higher educationtoward an agreed-upon reference framework. Sustain. Sci. 16, 13-29. doi: $10.1007 / \mathrm{s} 11625-020-00838-2$

Davis, H., and Goedegebuure, L. (2017). "Governance for sustainability in higher education," in Ethics in Higher Education: Values-Driven Leaders for the Future, eds D. Singh and C. Stückelberger (Geneva: Globethics.net Education Ethics), 217-230.

de Haan, G. (2010). The development of ESD-related competencies in supportive institutional frameworks. Int. Rev. Educ. 56, 315-328. doi: 10.1007/s11159-010-9157-9

Disterheft, A., Caeiro, S., Azeiteiro, U. M., and Leal Filho, W. (2015). Sustainable universities - a study of critical success factors for participatory approaches. J. Clean. Product. 106, 11-21. doi: 10.1016/j.jclepro.2014.01.030

Fadeeva, Z., and Mochizuki, Y. (2010). Higher education for today and tomorrow: university appraisal for diversity, innovation and change towards sustainable development. Sustain. Sci. 5, 249-256. doi: 10.1007/s11625-010-0106-0

Fazey, I., Schäpke, N., Caniglia, G., Hodgson, A., Kendrick, I., Lyon, C., et al. (2020). Transforming knowledge systems for life on Earth: visions of future systems and how to get there. Energy Res. Soc. Sci. 70:101724. doi: 10.1016/j.erss.2020.101724

Ferrer-Balas, D., Adachi, J., Banas, S., Davidson, C. I., Hoshikoshi, A., Mishra, A., et al. (2008). An international comparative analysis of sustainability transformation across seven universities. Int. J. Sustain. Higher Educ. 9, 295-316. doi: 10.1108/14676370810885907

Giesenbauer, B. and Müller-Christ, G. (2020). University 4.0: promoting the transformation of higher education institutions toward sustainable development. Sustainability 12:3371. doi: 10.3390/su12083371

Giesenbauer, B., and Tegeler, M. (2020) "The transformation of higher education institutions towards sustainability from a systemic perspective," in Universities as Living Labs for Sustainable Development, eds W. Leal Filho, A. L. Salvia, R. W. Pretorius, L. L. Brandli, E. Manolas, F. Alves, U. Azeiteiro, J. Rogers, C. Shiel, and A. Do Paco (Cham: Springer International Publishing), 637-650.

Glasser, H. (2005). The sustainability challenge: higher education for a higher purpose. Heartstone. 6, 23-31.

Helling, K. (2018). "Environmental campus Birkenfeld-a role model for universities on how to contribute to the implementation process of the sustainable development goals," in World Sustainability Series, Handbook of Sustainability Science and Research, Vol. 24, ed W. Leal Filho (Cham: Springer International Publishing), 539-551. doi: 10.1007/978-3-319-63007-6_33

Hoover, E., and Harder, M. K. (2015). What lies beneath the surface? The hidden complexities of organizational change for sustainability in higher education. J. Clean. Product. 106, 175-188. doi: 10.1016/j.jclepro.2014.01.081

Leal Filho, W., Shiel, C., Paço, A., Mifsud, M., Veiga Ávila, L., Londero Brandli, L. L., et al. (2019). Sustainable development goals and sustainability teaching at universities: falling behind or getting ahead of the pack? J. Clean. Product. 232, 285-294. doi: 10.1016/j.jclepro.2019.05.309

Lotz-Sisitka, H., Wals, A. E. J., Kronlid, D., and McGarry, D. (2015). Transformative, transgressive social learning: rethinking higher education pedagogy in times of systemic global dysfunction. Curr. Opin. Environ. Sustain. 16, 73-80. doi: 10.1016/j.cosust.2015.07.018

Lozano, R., Ceulemans, K., Alonso-Almeida, M., Huisingh, D., Lozano, F. J., Waas, T., et al. (2015). A review of commitment and implementation of sustainable development in higher education: results from a worldwide survey. J. Clean. Product. 108, 1-18. doi: 10.1016/j.jclepro.2014.09.048

Michelsen, G. (2016). Policy, politics and polity in higher education for sustainable development. In: Routledge Handbook of Higher Education for Sustainable
Development, eds M. Barth, G. Michelsen, I. Thomas, M. Rieckmann (Routledge), 40-55.

Niedlich, S., Kummer, B., Bauer, M., Rieckmann, M., and Bormann, I. (2019). Cultures of sustainability governance in higher education institutions: a multicase study of dimensions and implications. Higher Educ. Q. 74, 373-390. doi: $10.1111 /$ hequ. 12237

Orr, D. (1991). What is education for? Six myths about the foundations of modern education and six new principles to replace them. The Learning Revolution, 52-57. Available online at: https://www.eeob.iastate.edu/classes/EEOB-590A/ marshcourse/V.5/V.5a\%20What\%20Is\%20Education\%20For.htm (accessed April 12, 2021)

Purcell, W. M., Henriksen, H., and Spengler, J. D. (2019). Universities as the engine of transformational sustainability toward delivering the sustainable development goals: "living labs" for sustainability. Int. J. Sustain. Higher Educ. 20, 1343-1357. doi: 10.1108/IJSHE-02-2019-0103

Rieckmann, M. (2012). Future-oriented higher education: which key competencies should be fostered through university teaching and learning? Futures 44, 127-135. doi: 10.1016/j.futures.2011.09.005

Schmitt, C. T., and Palm, S. (2018). "Sustainability at German universities: the university of Hamburg as a case study for sustainability-oriented organizational development," in World Sustainability Series, Handbook of Sustainability Science and Research, Vol. 43, ed W. Leal Filho (Cham: Springer International Publishing), 629-645. doi: 10.1007/978-3-319-63007-6_39

Singer-Brodowski, M., Brock, A., Etzkorn, N., and Otte, I. (2018). Monitoring of education for sustainable development in Germany insights from early childhood education, school and higher education. Environ. Educ. Res. 25, 492-507. doi: 10.1080/13504622.2018.14 40380

Singer-Brodowski, M., Etzkorn, N., and von Seggern, J. (2019). One transformation path does not fit all - insights into the diffusion processes of education for sustainable development in different educational areas in Germany. Sustainability 11:269. doi: 10.3390/su110 10269

Sterling, S. (2004). "Higher education, sustainability, and the role of systemic learning," in Higher Education and the Challenge of Sustainability: Problematics, Promise, and Practice, eds P. B. Corcoran and A. E. J. Wals (Dordrecht: Kluwer Academic Publishers), 49-70.

Sterling, S. (2011). Transformative learning and sustainability: sketching the conceptual ground. Learn. Teach. Higher Educ. 5, 17-33.

Sterling, S. (2013). “The sustainable university: challenge and response," in The Sustainable University. Progress and Prospects, eds S. Sterling, L. Maxey, and H. Luna (London: Routledge), 17-50.

Trencher, G., Yarime, M., McCormick, K. B., Doll, C. N. H., and Kraines, S. B. (2014). Beyond the third mission: exploring the emerging university function of co-creation for sustainability. Sci. Public Policy 41, 151-179. doi: $10.1093 /$ scipo $1 /$ sct044

Vogt, M., and Weber, C. (2020). The role of universities in a sustainable society. Why value-free research is neither possible nor desirable. Sustainability 12:2811. doi: $10.3390 /$ su 12072811

Wals, A. E. J., Tassone, V. C., Hampson, G. P., and Reams, J. (2016). "Learning for walking the change: eco-social innovation through sustainability-oriented higher education," in Routledge Handbook of Higher Education for Sustainable Development, eds M. Barth, G. Michelsen, M. Rieckmann, and I. Thomas (London: Routledge), 25-39.

Zilahy, G., and Huisingh, D. (2009). The roles of academia in regional sustainability initiatives. J. Clean. Product. 17, 1057-1066. doi: $10.1016 /$ j.jclepro.2009.03.018

Conflict of Interest: The authors declare that the research was conducted in the absence of any commercial or financial relationships that could be construed as a potential conflict of interest.

Copyright (c) 2021 Bauer, Rieckmann, Niedlich and Bormann. This is an open-access article distributed under the terms of the Creative Commons Attribution License (CC $B Y)$. The use, distribution or reproduction in other forums is permitted, provided the original author(s) and the copyright owner(s) are credited and that the original publication in this journal is cited, in accordance with accepted academic practice. No use, distribution or reproduction is permitted which does not comply with these terms. 